\title{
Study on Environmental Accounting Information Disclosure of Coal Mining and Washing Industry's Listed Companies in China
}

\author{
Lu Zeng ${ }^{1,}$, Xi Sun $^{1, b}$ \\ ${ }^{1}$ College of Mobile Telecommunications, Chongqing University of Posts and Telecommunications, \\ Chongqing, China \\ a zengluaa@163.com, b sunxi@21cn.com
}

\begin{abstract}
Keywords: Environmental Accounting; Information Disclosure; Listed Companies; Coal Mining and Washing Industry
\end{abstract}

Abstract. Environmental accounting information disclosure can encourage enterprises to protect the ecological environment, support scientific and technological innovation, promote the upgrading of industrial structure, and take the road of sustainable development. In twenty-first Century, more and more countries began to build a low-carbon economy, and began to focus on the harmonious development between human and nature. Coal, as one of the main energy sources of human beings, brings heat and environmental pollution. The overall situation is not optimistic, based on the research of environmental accounting information disclosure of coal mining and washing industry's listed companies. The main problems are lacks of voluntary disclosure, uniform form and content in disclosure, environmental accounting standards and supervision. In the end, it's proposed to improve disclosure of coal mining and washing industry's companies, such as improving the governance strctrure of listed companies, improving the laws and regulations related to environmental accounting disclosure, regulating the environmental accounting standards, and strengthening government supervision and social supervision.

\section{Introduction}

China is a big country not only on resource and energy consumption, but also on environmental pollutant emissions. Waste of resources, environmental pollution and ecological deterioration has a serious impact on people's life and economic development [1]. It has become a very urgent strategic task that protecting resources and improving environment drive the sustainable development of China's economy. Enterprise is not only an important factor leading to environmental pollution, but also a dominant force in the treatment of environmental pollution. Coal is one of the main sources of energy used since eighteenth Century, which is usually used in power generation and heating [2, 3]. At the same time, the use of coal has also brought many environmental problems. Coal mining and washing industry's environmental protection measures a country's level of environmental protection. Coal mining and washing industry's listed companies as a representative of modern enterprises reach leading level in the corporate governance structure, management system and accounting information disclosure. For coal mining and washing industry's listed companies, the disclosure of environmental accounting information can not only improve the level of management, but also enhance social responsibility awareness to a certain extent, and establish a good corporate image in the public [4, 5]. From the perspective of building a low-carbon economy, it's an extremely urgent problem that coal mining and washing industry's listed companies strengthen accounting information disclosure. At present, the research of environmental accounting information disclosure is lagging behind and the practice is slow progress in China [6]. The research on environmental accounting information disclosure of coal mining and washing industr's listed companies has theoretical and practical significance. 


\section{Present Situation of Environmental Accounting Information Disclosure of Coal Mining and Washing Industry's Listed Companies}

According to "listed companies industry classification results in the third quarter of 2015" released by China Securities Regulatory Commission, the number of coal mining and washing industry's listed companies is 28 . Finally, 24 companies are selected to study, eliminating one company which stock code is 600652 because of the changing of major business, and eliminating three companies which stock codes are 600395, 600714 and 601666 because of the lack of company homepage. The results of the study on the disclosure of environmental accounting information are shown in table 1.

Table 1 environmental information disclosure of coal mining and washing industry's listed companies

\begin{tabular}{|c|c|c|c|c|}
\hline Stock Code & Stock Abbreviation & Company Name & Company Website & Disclosure of Environmental Information \\
\hline 000552 & Jingyuan coal power & $\begin{array}{l}\text { Gansu Jingyuan Coal Industry } \\
\text { and Electricity Power Co., Ltd }\end{array}$ & http://www.jymdgs.com & No environmental information disclosure on the company's homepage. \\
\hline 000571 & Sundiro A & $\begin{array}{l}\text { New continent Cmi Holdings } \\
\text { Ltd }\end{array}$ & http://www.sundiro.com & $\begin{array}{l}\text { The company's homepage has an "About Sundiro" column which has } \\
\text { "social responsibility" plate. Environmental indicators about Sundiro } \\
\text { Honda motorcycle are listed in it simply. }\end{array}$ \\
\hline 000780 & Ping Zhuang energy & $\begin{array}{l}\text { Inner Mongolia Ping Zhuang } \\
\text { energy Co., Ltd }\end{array}$ & $\begin{array}{l}\text { http://www.nmgpzny.co } \\
\text { m }\end{array}$ & No environmental information disclosure on the company's homepage. \\
\hline 000937 & Jizhong energy & $\begin{array}{l}\text { Jizhong Energy Resources Co., } \\
\text { Ltd }\end{array}$ & http://www.jnny.com.cn & $\begin{array}{l}\text { The company's homepage has a "sustainable development" column } \\
\text { which has "information disclosure" plate. Social responsibility report in } \\
2010 \text { can be downloaded. }\end{array}$ \\
\hline 000968 & Coal gasification & $\begin{array}{l}\text { Taiyuan Coal Gasification Co., } \\
\text { Ltd }\end{array}$ & http://www.tymqh.com & $\begin{array}{l}\text { The company's homepage has a "social responsibility" column which } \\
\text { has "environmental protection and sustainable development" plate. The } \\
\text { amount of environmental protection spending in } 2014 \text { is clearly shown. }\end{array}$ \\
\hline 000983 & Xishan coal electricity & $\begin{array}{l}\text { Xishan Coal Electricity Group } \\
\text { Co., Ltd }\end{array}$ & http://www.xsmd.com.cn & No environmental information disclosure on the company's homepage. \\
\hline 002128 & Open cut coal & $\begin{array}{l}\text { Huolinhe open cut coal } \\
\text { industry corporation limited of } \\
\text { Mongolia }\end{array}$ & $\begin{array}{l}\text { http://www.nmghlhltmy.c } \\
\text { om }\end{array}$ & $\begin{array}{l}\text { The company's homepage has a "social responsibility" column which } \\
\text { has "social responsibility report" section. Social responsibility report in } \\
2013 \text { can be downloaded. The investment expenditure, the name and the } \\
\text { concentration of the main pollutants in the mine ecological management } \\
\text { are listed from the quantitative and qualitative description. }\end{array}$ \\
\hline 600121 & Zhengzhou Coal Electric & $\begin{array}{l}\text { Zhengzhou Coal and Electric } \\
\text { Co., Ltd }\end{array}$ & http://www.zzce.com.cn & No environmental information disclosure on the company's homepage. \\
\hline 600123 & Lanhua Sci-tech Venture & $\begin{array}{l}\text { Shanxi Lanhua Sci-tech } \\
\text { Venture Co., Ltd }\end{array}$ & $\begin{array}{l}\text { http://www.chinalanhua.c } \\
\text { om }\end{array}$ & $\begin{array}{l}\text { The company's homepage has a "social responsibility" column, social } \\
\text { responsibility reports from } 2008 \text { to } 2012 \text { in which. In the recent social } \\
\text { responsibility report in } 2012 \text {, the content of green development, the main } \\
\text { pollutant emissions indicators, and the amount of investment in } \\
\text { environmental protection has been shown specificly. }\end{array}$ \\
\hline 600157 & Wintime energy & Wintime Energy Co., Ltd & http://www.wtecl.com & No environmental information disclosure on the company's homepage. \\
\hline 600188 & Yanzhou coal & $\begin{array}{l}\text { Yanzhou Coal Mining } \\
\text { Company Limited }\end{array}$ & $\begin{array}{l}\text { http://www.yanzhoucoal. } \\
\text { com.cn }\end{array}$ & No environmental information disclosure on the company's homepage. \\
\hline 600348 & Yangquan coal & $\begin{array}{l}\text { Yangquan Coal Mining } \\
\text { (Group) Limited by Share Ltd }\end{array}$ & http://www.ymjt.com.cn & $\begin{array}{l}\text { The company's homepage has "science and technology innovation" } \\
\text { column which has "energy saving and environmental protection" plate. } \\
\text { The monitoring of pollution sources in the cement plant and the thermal } \\
\text { power plant is reflected. The latest update date is January } 9,2014 \text {. }\end{array}$ \\
\hline 600397 & Anyuan coal & JiangXi Energy Group Gorp & http://www.jxcgc.com & No environmental information disclosure on the company's homepage. \\
\hline 600403 & Dayou energy & $\begin{array}{l}\text { Henan Dayou Energy Limited } \\
\text { by Share Ltd }\end{array}$ & http://hndayou.com.cn & $\begin{array}{l}\text { The company's homepage has "into Dayou" column which has "social } \\
\text { responsibility" plate. There are news related to the environment, but the } \\
\text { latest update date is July } 2,2012 \text {. }\end{array}$ \\
\hline 600508 & Shanghai energy & $\begin{array}{l}\text { Shanghai Datun Energy Co., } \\
\text { Ltd }\end{array}$ & http://www.sdtny.com & No environmental information disclosure on the company's homepage. \\
\hline 600971 & Hengyuan coal & $\begin{array}{lr}\text { Anhui } & \text { Hengyuan } \\
\text { Coal-electricity Group Co., Ltd }\end{array}$ & $\begin{array}{l}\text { http://www.ahhymd.com. } \\
\text { cn }\end{array}$ & No environmental information disclosure on the company's homepage. \\
\hline 601001 & Datong coal & $\begin{array}{l}\text { Datong Coal Mining Limited } \\
\text { by Share Ltd }\end{array}$ & http://www.dtmy.com.cn & No environmental information disclosure on the company's homepage. \\
\hline 601088 & China Shenhua & China Shenhua Energy Co., Ltd & $\begin{array}{l}\text { http://www.shenhuachina } \\
\text {.com }\end{array}$ & $\begin{array}{l}\text { The company's homepage has "Social Responsibility Report" column in } \\
\text { which the } 2014 \text { social responsibility can be downloaded. The contents } \\
\text { about the clean environmental protection, comprehensive utilization of } \\
\text { water resources, emissions of pollutants and emissions reduction is } \\
\text { descripted in detail. }\end{array}$ \\
\hline 601101 & Haohua energy & $\begin{array}{lll}\text { Beijing Haohua } & \text { Energy } \\
\text { Resource Co., Ltd } & \\
\end{array}$ & http://www.bjhhny.com & No environmental information disclosure on the company's homepage. \\
\hline 601225 & Shaanxi coal & $\begin{array}{l}\text { Shaanxi Coal Mining Company } \\
\text { Limited }\end{array}$ & http://www.shxcoal.com & $\begin{array}{l}\text { The company's homepage has "corporate social responsibility" column } \\
\text { which has "friendly environment" plate. The disclosure of } \\
\text { environmental information is mainly through the news and the latest } \\
\text { update date is January } 21,2014 \text {. }\end{array}$ \\
\hline 601699 & $\begin{array}{l}\text { Lu'an environmental } \\
\text { energy }\end{array}$ & $\begin{array}{l}\text { Shanxi Lu'an environmental } \\
\text { energy development Limited } \\
\text { by Share Ltd }\end{array}$ & http://www.luanhn.com & No environmental information disclosure on the company's homepage. \\
\hline 601898 & China coal energy & $\begin{array}{l}\text { Chinese coal energy Limited by } \\
\text { Share Ltd }\end{array}$ & $\begin{array}{l}\text { http://www.chinacoalener } \\
\text { gy.com }\end{array}$ & $\begin{array}{l}\text { The company's homepage has "safety, health, and environmental } \\
\text { protection" column in which the social responsibility report from } 2009 \\
\text { to } 2013 \text { can be downloaded. }\end{array}$ \\
\hline 601918 & National Investment Xinji & $\begin{array}{l}\text { National Investment Xinji } \\
\text { Energy Co., Ltd }\end{array}$ & http://www.sdic.com.cn & $\begin{array}{l}\text { The company's homepage has "social responsibility" column in which } \\
\text { the social responsibility report from } 2008 \text { to } 2014 \text { can be downloaded. }\end{array}$ \\
\hline 900948 & Yitai B & $\begin{array}{l}\text { Inner Mongolia Yitai Coal } \\
\text { Limited by Share Ltd }\end{array}$ & http://www.yitaicoal.com & $\begin{array}{l}\text { The company's homepage has "social responsibility" column in which } \\
\text { the social responsibility report from } 2008 \text { to } 2014 \text { can be downloaded. } \\
\text { The } 2014 \text { social responsibility report publishes the company's } \\
\text { environmental responsibility. }\end{array}$ \\
\hline
\end{tabular}


From table 1, it can be seen, 12 companies of coal mining and washing industry don't disclose environmental information in their companies' homepage and the relative proportion reached $50 \%$. 12 companies disclose environmental information, but only 4 companies accounted for $16.7 \%$ of all samples renew the information promptly. The 4 company's stock codes and abbreviations are "000968 Coal gasification”, "601088 China Shenhua”, "601918 National Investment Xinji” and "900948 Yitai B". Therefore, the overall situation on environmental information disclosure of coal mining and washing industry's listed companies is not optimistic in China.

Further analysis of better four listed companies in environmental information disclosure shows that the four listed companies have common characteristics. The strategic objectives of "000968 Coal gasification" are to create the most competitive enterprise in coal refining and focus on investment in environmental protection and scientific and technological innovation. "601088 China Shenhua" is taking the innovation driving route, which research team led by Yuzhuo Zhang who is in China Academy of Engineering. "601918 National Investment Xinji" is the State Development and Investment Company's subsidiary and the status of nature enterprise decides it to serve national strategic principle, focus on investment in basic industries, ecological environment protection, and sci-tech innovation. "900948 Yitai B" adheres to take the road of sustainable development, to promote the upgrading of the industrial structure, to enhance the professional level and competitive strength and stands the high level such as "China's 863". It can be seen from the above analysis, science and technology innovation is the source of environmental protection. Enterprises only attach importance to scientific and technological innovation, in order to achieve success in environmental protection and have force of public environmental information disclosure.

\section{Problems of Environmental Accounting Information Disclosure of Coal Mining and Washing Industry's Listed Companies}

\section{Lack of Voluntary Disclosure}

Most listed companies of coal mining and washing industry in China are lack of willingness to disclose environmental accounting information. Three reasons can be found to explain why these listed companies in coal mining and washing industry are not willing to disclose environmental accounting information voluntarily.

The first possible reason is that many enterprises including listed companies in coal mining and washing industry are extensive production and the ability of environmental protection is weak. The content of disclosure is not good, so these companies do not want to disclose.

Secondly, currently laws and regulations relating environment don't enforce enterprises to disclose environmental accounting information in China, although these laws and regulations have played a certain role in improving the environment such as pollutant discharge and waste disposal.

Thirdly, the benefit of voluntary disclosure is not obvious. In the tax law, some stipulations about the tax and fee remission which encourages the enterprise to pay attention to the environment question are difficult to confirm and execute.

\section{Lack of Uniform Form and Content in Disclosure}

The disclosures of environmental accounting information of coal mining and washing industry's listed companies are in various forms.Some listed companies disclose environmental information by responsibility report, some companies disclose by news, and others set the plate in their companys' homepage to disclose information related to environment.

As for the content of disclosure, some listed companies disclose the amount of spending in environmental protection and utilization, some listed companies disclose indicators of pollutant emissions, some listed companies disclose the quantitative data, and some listed companies disclose the qualitative analysis. Lack of uniform standards of disclosure makes the information users feel confused when they compare, analyze and use information. 


\section{Lack of Environmental Accounting Standards}

The disclosure of environmental accounting information is lack of environmental accounting standards. Because the disclosure of environmental accounting information is still in the primary stage in China, the environmental accounting information disclosure is the lack of a unified standard. Japan has a number of environmental accounting standards which go back to 1999, so Japan's environmental accounting has come to the front. Even those listed companies who disclose the environmental information in China, do not fully stand in the perspective of accounting disclosure, which can not be believed full accounting disclosure stringently.

\section{Lack of Supervision}

The disclosure of environmental accounting information is lack of supervision mechanism. Disclosure or not, true information or false information, all depend on consciousness of enterprises. So, those enterprises do well in disclosure such as state own enterprises, strong-innovation enterprise and strong-power enterprises. Enterprise managers have poor awareness in environmental information, and have not yet established the concept of green accounting. Many enterprises only focus on short-term interests, destruct the natural environment, and ignore the long-term development of future generations. Based on this situation, many enterprises are not willing to disclose environmental information too much, which requires the government and the public to supervise in order to strengthen the disclosure of environmental accounting information.

\section{Measures on Improving Disclosure of Coal Mining and Washing Industry's Listed Companies}

\section{Improve the Governance Structure of theListed Companies}

In order to strengthen the enterprise's self disclosure consciousness, the corporate governance structure should be improved firstly, such as: the establishment of the environmental protection department of the enterprise that aims to being responsible for corporate environmental problems. At the same time, environmental accounting information disclosure requires the combination of environmental protection department and accounting department. Only managers of enterprises enhance the awareness of environmental protection reflected in the establishment of institutions, enterprises will enhance the willingness to disclose environmental accounting information.

\section{Improve the Laws and Regulations Related to Environmental Accounting Disclosure}

The laws and regulations of environmental accounting information disclosure are very few in China and existing laws and regulations' articles are contradictions. It's necessary to establish the laws and regulations related to environmental accounting disclosure from the national legislative level. The support of the state environmental protection department is also very necessary in improving the legal system of environmental information disclosure.State environmental protection departments should make the basic legal norms according to its function, and establish the environmental protection regulations related to financial accounting in conjunction with relevant departments, urging the environment accounting information disclosure to further standardization. Departments in charge of different industries should refine requirements according to their characteristics of the industry under the general laws and regulations. Coal mining and washing industry authority should explain content and form of disclosure specificly.

\section{Regulate the Environmental Accounting Standards}

In order to strengthen the development of environmental accounting standards, those developed countries that have had environmental accounting standards such as Japan, Europe and the United States, should be learned hardly. Moreover, the environmental accounting standerds will be drawn up combing with the actual situation in China. Applying the environmental accounting standards, the cost of ecological environment is incorporated into the current product cost accounting system, which makes the cost of enterprise products reflect the cost of resources and environment truly. In the role of market competition mechanism, enterprises are forced to increase investment in technological reform and development of advanced clean production technology, to eliminate backward production capacity, and to achieve energy saving and environmental protection purposes. 


\section{Strengthen Government Supervision and Social Supervision}

Firstly, the government has the responsibility to supervise and manage the environmental accounting information. Specifically speaking, it's necessary to strengthen prior supervision and expost supervision of the listed companies' environmental accounting information, increase investment of constructing the electronic system of information disclosure, and improve the efficiency of the disclosure and the value of the use of information. Government departments actively guide listed companies to disclose environmental accounting information voluntarily and consciously fulfill corporate social responsibility.

Secondly, social supervision should play its due role. The company's trade union organizations, news media and other environmental organizations should give full play to their role of public opinion and supervision, improving the authenticity and reliability of environmental accounting information disclosure.

\section{Conclusions}

(a) The overall situation on environmental accounting information disclosure of coal mining and washing industry's listed companies is not optimistic in China. Research shows that nearly $50 \%$ of the listed companies did not carry out environmental information disclosure in coal mining and washing industry. Only 4 listed companies accounted for $16.7 \%$ of all samples renew the information promptly in coal mining and washing industry.

(b) The disclosure has various forms, such as social responsibility report, news report and homepage list. The content of disclosure is not uniform. Some companies disclose the investment expenditure; some companies disclose the name and the concentration of the main pollutants; the others disclose environmental information through qualitative description.

(c) The environmental accounting standard is lack in China. Present laws and regulations related to environmental accounting information disclosure can not completely guide enterprises to carry out environmental accounting information disclosure.

(d) The supervision of environmental accounting disclosure is lack in China. Government supervision and social supervision are in the absence.

\section{References}

[1] J. Christine: Journal of Cleaner Production, Vol. 14 (2006), p. 1190.

[2] Shouhua Zhou and Chunhua Tao: Accounting Research Vol. 2(2012), p. 3-10 (In Chinese)

[3] Zhongwen Liu and Linlin Zhang: Research on Economics and Management Vol. 12(2007), p. 78-84 (In Chinese)

[4] Y.b. Tang, Q.j. Xu and Y.l. Min: Advanced Materials Research, Vol. 1073-1076 (2014), p. 2679.

[5] S.M. Williams: The International Journal of Accounting, Vol. 34 (1999), p. 209.

[6] T. Eugenio, I.C. Lourenco, and A.I. Morais: Social Responsibility Journal, Vol. 6 (2010), p. 286. 